\title{
STRATEGI PEMASARAN SUSU KAMBING DI BOGOR
}

\author{
(Marketing Strategy of Goat Milk in Bogor) \\ Lalita Paraduhita Martha ${ }^{1}$, Ma'mun Sarma ${ }^{1}$, Mukhamad Najib ${ }^{1}$ \\ ${ }^{1}$ Mahasiswa S2 Program Studi Ilmu Manajemen IPB \\ ${ }^{1}$ Dosen Program Studi Ilmu Manajemen IPB \\ ${ }^{1}$ Dosen Program Studi Ilmu Manajemen IPB
}

\begin{abstract}
Milk consumption enhancement that not matched the number of domestic supply which still rely on cow's milk makes Indonesia continue to importing milk, almost 70 percent of the total needed. An alternative to the fulfilment is to increase the supply from other livestock such as dairy goats. Bogor is a potential area for the development of dairy goat farm. The aims of this research are to: 1) analyze the goat's milk business potency in Bogor which considering the internal and external factors; and 2) develop an effective marketing strategy in order to improve the goat milk business in Bogor. The data was used in this research are primary and secondary data. The interviews for data collection conducted on October 2014 through November 2016, using a questionnaire tools with Strengths-Weaknesses-Opportunities-Threats (SWOT) and Analytical Hierarchy Process (AHP) approach. The research respondents amounted to 9 for SWOT and 7 to AHP. The respondents located in Bogor consisted of academics, dairy goat breeders, goat's milk seller/agent, agricultural bureau of the city also animal husbandry bureau and fisheries of the district. The internal factor has score of 2.701 of goat milk business in the city and district of Bogor, while the external factor has score of 3.085. Merging the two matrices put goat's milk business into cell II, that is the grow and build cells. The recommendation of key strategic for goat's milk marketing which effective based on the results of AHP with score of 0.202 is to make the development of goat's milk business as part of government road map as an effort to optimize the potential of the city and district of Bogor.
\end{abstract}

Keywords: AHP, goat milk, marketing strategy, SWOT

\section{ABSTRAK}

Peningkatan konsumsi susu tidak diimbangi dengan jumlah pasokan dalam negeri yang masih mengandalkan susu sapi, membuat Indonesia terus melakukan impor, bahkan hampir 70 persen dari jumlah kebutuhan. Salah satu alternatif untuk pemenuhannya yaitu dengan menambah pasokan dari ternak lainnya seperti kambing perah. Bogor merupakan daerah potensial untuk pengembangan usaha peternakan kambing perah. Penelitian ini dilakukan dengan tujuan untuk: 1) menganalisis potensi usaha susu kambing di Bogor dengan mempertimbangkan faktor internal dan eksternalnya; dan 2) menyusun strategi pemasaran yang efektif guna meningkatkan usaha susu kambing di Bogor. Jenis data yang digunakan dalam penelitian ini adalah data primer dan sekunder. Wawancara untuk pengumpulan data dilakukan pada bulan Oktober 2014 sampai November 2016, menggunakan alat bantu kuesioner dengan pendekatan Strengths-WeaknessesOpportunities-Threats (SWOT) dan Analytical Hierarchy Process (AHP). Responden dalam penelitian ini berjumlah 9 orang untuk SWOT dan 7 orang untuk AHP. Responden tersebut berlokasi di Bogor, terdiri dari akademisi, peternak kambing perah, agen/penjual susu kambing, dinas pertanian serta dinas peternakan dan perikanan. Faktor internal usaha susu kambing di kota dan kabupaten Bogor memiliki skor sebesar 2,701, sedangkan faktor eksternalnya memiliki skor sebesar 3,085. Penggabungan kedua matriks tersebut menempatkan usaha susu kambing berada di sel II, yaitu sel tumbuh dan membangun (grow dan build). Rekomendasi strategi utama untuk pemasaran susu kambing yang 
efektif berdasarkan hasil AHP dengan skor 0,202 adalah menjadikan pengembangan susu kambing sebagai bagian dari road map pemerintah dalam upaya mengoptimalkan potensi kota dan kabupaten Bogor.

Kata kunci: AHP, strategi pemasaran, susu kambing, SWOT

\section{PENDAHULUAN}

\section{Latar Belakang}

Seiring semakin terbukanya arus informasi, salah satunya berimbas pada berkembangnya tingkat pengetahuan masyarakat yang berakibat pada peningkatan konsumsi berbagai sumber protein hewani seperti daging, susu dan telur. Pola peningkatan tergambar pada data konsumsi dalam negeri, dimana diantara produk ternak tersebut yang paling terlihat peningkatannya adalah konsumsi susu dalam negeri (BPS 2016). Laju pertumbuhan rata-rata konsumsi susu mencapai 7.0 persen per tahun lebih tinggi dari laju pertumbuhan produksi susu nasional yang hanya 3.29 persen per tahun. Artinya, jumlah produksi susu sapi nasional masih belum mencukupi permintaan atau kebutuhan konsumsi susu dalam negeri.

Belum terpenuhinya kebutuhan untuk konsumsi susu dalam negeri, membuat pemerintah Indonesia saat ini masih melakukan impor susu sekitar 70 persen untuk menjaga ketersediaan susu nasional. Ketergantungan yang sangat tinggi terhadap bahan baku susu impor dalam rangka memenuhi kebutuhan susu nasional memiliki beberapa kelemahan, yaitu: menguras devisa negara, tidak ada jaminan terhadap keamanan pangan jangka panjang, dapat meningkatkan pengangguran dan mengurangi kesejahteraan peternak, serta menurunkan konsumsi susu segar yang berbahan baku SSDN (susu segar dalam negeri) (Farid dan Sukesi 2011). Maka dari itu, sangat diperlukan kemandirian produksi susu nasional, agar kecenderungan impor yang menambah ketergantungan bangsa Indonesia terhadap bangsa lain dapat dikurangi. Farid dan Sukesi (2011) merumuskan beberapa strategi untuk mengembangkan persusuan nasional, yaitu peningkatan populasi sapi perah, fasilitasi kebutuhan lahan, kemudahan investasi industri persusuan, pengembangan kemampuan peternak, fasilitasi kebutuhan modal, meningkatkan serapan susu segar, mengembangkan kemitraan yang sehat, dan memperkuat pasar susu domestik.

Apabila negara harus melakukan impor susu dari negara lain untuk memenuhi permintaan pasar dalam negeri, hal tersebut berarti kebutuhan akan susu sangat tinggi di 
Indonesia, tetapi belum dapat dipenuhi oleh produsen lokal yang seharusnya mendapat dukungan serta dijaga dengan baik oleh pemerintah, sehingga Indonesia masih perlu mengimpor dari negara lain. Iwantoro (2014) mengemukakan bahwa permasalahan produksi susu di Indonesia karena Indonesia hanya mengandalkan produksi susu sapi saja, padahal banyak negara lain yang sudah menggunakan alternatif lain, seperti susu kerbau di negara Asia Selatan (India, Pakistan, Bangladesh, Mesir, Italia dan Brazil), susu kambing di Timur Tengah dan Afrika, dan susu kuda di Asia Tengah. Iwantoro (2014) juga mengatakan bahwa memang susu kambing tidak sepopuler susu sapi tapi susu kambing mulai populer dan signifikan meluas permintaannya karena dipercaya dapat menyembuhkan penyakit dan untuk menjaga kesehatan, oleh karenanya saat ini adalah kesempatan yang paling baik untuk mengembangkan pemasaran susu kambing.

Bogor merupakan daerah bagian dari provinsi Jawa Barat yang berada dekat dengan ibukota negara. Dengan melihat potensi sumber daya alam dan manusia yang dimiliki baik oleh kabupaten maupun kota Bogor, sebenarnya sangat potensial untuk mengembangkan usaha peternakan kambing perah yang berkontribusi terhadap pemenuhan kebutuhan akan susu kambing nasional. Usaha peternakan kambing perah di Bogor masih merupakan usaha skala kecil, sehingga masih sangat memungkinkan untuk dikembangkan. Untuk mengembangkannya diperlukan strategi pengembangan yang efektif. Strategi tersebut mencakup strategi pemasaran sebagai alternatif strategi pengembangan usaha susu kambing.

\section{Perumusan Masalah}

1. Bagaimanakah potensi usaha susu kambing di Bogor dengan mempertimbangkan faktor internal dan eksternalnya.

2. Bagaimanakah strategi pemasaran yang efektif guna meningkatkan usaha susu kambing di Bogor?

\section{Tujuan Penelitian}

1. Menganalisis potensi usaha susu kambing di Bogor dengan mempertimbangkan faktor internal dan eksternalnya.

2. Menyusun strategi pemasaran yang efektif guna meningkatkan usaha susu kambing di Bogor.

\section{METODE PENELITIAN}




\section{Lokasi dan Waktu Penelitian}

Penelitian dilaksanakan di beberapa lokasi di kabupaten dan kota Bogor, yaitu di beberapa peternakan yang berada di kota dan kabupaten Bogor, dinas pertanian kota Bogor, dinas peternakan dan perikanan kabupaten Bogor, agen/penjual susu kambing di Bogor dan akademisi. Peternakan tersebut yaitu PT. Caprito Agrindo Prima, Cordero Farm, Bangun Karso Farm, Mandiri Jaya Farm dan UD. Harokah Barokah. Penelitian ini dilaksanakan pada bulan Oktober 2014 sampai dengan November 2016.

\section{Metode Penelitian}

Penelitian ini menggunakan metode wawancara dengan kuesioner sebagai alat menghimpun informasi dari para responden mengenai usaha susu kambing di Bogor. Pertama untuk menganalisis kekuatan dan kelemahan juga peluang dan ancaman yang selama ini berjalan dalam proses pemasaran susu kambing di Bogor digunakan teknik analisis SWOT (Strengths-Weaknesses-Opportunities-Threats). Selanjutnya, hasil dari analisis SWOT yang berupa strategi kemudian diberikan peringkat yang dianalisis menggunakan AHP (Analytical Hierarchy Process), untuk kemudian dihasilkan strategi pemasaran yang efektif sebagai rekomendasi yang sebaiknya dilakukan untuk meningkatkan usaha susu kambing di Bogor.

\section{Jenis dan Cara Pengumpulan Data}

Metode pengambilan sampel dalam penelitian ini adalah non-probability sampling, yaitu pemilihan elemen populasi tidak menggunakan proses random, sehingga anggota populasi dipilih berdasarkan pertimbangan tertentu atau berdasarkan alasan kemudahan saja. Akibatnya anggota populasi yang lain tidak memiliki peluang untuk terpilih. Peneliti menggunakan convenience sampling, atau dengan kata lain peneliti menarik anggota populasi berdasarkan kemudahannya ditemui atau ketersediaan anggota populasi saja.

\section{HASIL DAN PEMBAHASAN}

\section{Analisis Matriks IFE Pemasaran Susu Kambing di Bogor}

Faktor internal usaha susu kambing di kota dan kabupaten Bogor memiliki total skor internal sebesar 2.701 (Tabel 1). Menurut David (2009), total skor di atas 2.5 mencirikan posisi yang cukup kuat secara internal dan eksternal, sedangkan di bawahnya menunjukkan posisi yang lemah. Hal tersebut menunjukkan bahwa posisi internal usaha susu kambing 
saat ini kuat dari segi internalnnya, yaitu mampu menggunakan kekuatan untuk menutup kelemahan usaha susu kambing. Kekuatan utama yang mendukung usaha susu kambing adalah "kepercayaan masyarakat akan khasiat susu kambing yang baik bagi kesehatan", dengan skor sebesar 0.368. Kelemahan usaha susu kambing di kota dan kabupaten Bogor adalah "skala usaha kecil", dengan skor sebesar 0.134.

Tabel 1 Matriks IFE Pemasaran Susu Kambing di Bogor

FAKTOR INTERNAL Bobot Rating Skor

\section{Kekuatan}

Memiliki beberapa kandungan nutrisi yang lebih baik dari susu

sapi

Lebih mudah dicerna dibandingkan susu sapi

$\begin{array}{lll}0,089 & 4 & 0.356 \\ 0,085 & 4 & 0,340\end{array}$

Pemeliharan kambing perah lebih mudah dan murah ketimbang

sapi perah

$0,070 \quad 3 \quad 0,210$

Kepercayaan masyarakat akan khasiat susu kambing yang baik

bagi kesehatan

$\begin{array}{lll}0,092 & 4 & \mathbf{0 , 3 6 8} \\ 0,083 & 3 & 0,249 \\ 0,078 & 3 & 0,234\end{array}$

\section{Kelemahan}

Skala usaha kecil

Kurangnya perhatian dari pemerintah

$\begin{array}{lll}0,067 & 2 & \mathbf{0 , 1 3 4} \\ 0,063 & 2 & 0,126 \\ 0,061 & 2 & 0,122\end{array}$

Kurangnya promosi

Tidak adanya GKSI atau industri untuk menampung produksi

susu kambing

$0,064 \quad 2 \quad 0,128$

Pemasaran masih sendiri-sendiri atau tidak ada wadah pemersatu

Sifat susu mudah rusak

$\begin{array}{lll}0,061 & 2 & 0,122\end{array}$

Harga susu kambing relatif mahal dibandingkan susu sapi

$0,062 \quad 2 \quad 0,124$

Dual fungsi peternak, sebagai produsen dan pemasar

\section{Total}

$\begin{array}{lll}0,062 & 1 & 0,062 \\ 0,063 & 2 & 0,126 \\ & & \mathbf{2 , 7 0 1}\end{array}$

\section{Analisis Matriks EFE Pemasaran Susu Kambing di Bogor}

Faktor eksternal usaha susu kambing di kota dan kabupaten Bogor memiliki total skor internal sebesar 3.085 (Tabel 2). Menurut David (2009), total skor di atas 2.5 
mencirikan posisi yang cukup kuat secara internal dan eksternal, sedangkan di bawahnya menunjukkan posisi yang lemah. Hal tersebut menunjukkan bahwa posisi eksternal usaha susu kambing saat ini kuat dari segi eksternalnnya, yaitu mampu memanfaatkan peluang dan menghindari ancaman. Peluang terbesarnya adalah "pasar yang masih sangat terbuka luas“, dengan skor 0.480 , sedangkan ancaman utama pada usaha susu kambing adalah "peminat susu kambing tersegmentasi“, dengan skor sebesar 0.300 .

Tabel 2 Matriks EFE Pemasaran Susu Kambing di Bogor

\begin{tabular}{|c|c|c|c|}
\hline FAKTOR EKSTERNAL & Bobot & Rating & Skor \\
\hline \multicolumn{4}{|l|}{ Peluang } \\
\hline Permintaan susu kambing cenderung meningkat & 0.108 & 3 & 0.324 \\
\hline Peningkatan kesadaran masyarakat akan kesehatan & 0.115 & 4 & 0.460 \\
\hline Pasar yang masih sangat terbuka luas & 0.120 & 4 & 0.480 \\
\hline Belum ada industri yang menguasai pasar & 0.097 & 3 & 0.291 \\
\hline Produksi susu berapapun akan terserap pasar & 0.098 & 3 & 0.294 \\
\hline \multicolumn{4}{|l|}{ Ancaman } \\
\hline Masuknya susu kambing bubuk dari luar negeri & 0.075 & 2 & 0.150 \\
\hline Peminat susu kambing tersegmentasi & 0.075 & 4 & $\mathbf{0 . 3 0 0}$ \\
\hline Permintaan susu kambing biasanya musiman & 0.079 & 3 & 0.237 \\
\hline Tidak merupakan produk daily consumption & 0.073 & 2 & 0.146 \\
\hline \multicolumn{4}{|l|}{$\begin{array}{l}\text { Pemahaman masyarakat bahwa susu kambing hanya } \\
\text { dikonsumsi sebagai obat atau alternatif penyembuhan saja }\end{array}$} \\
\hline $\begin{array}{l}\text { Pengenaan pajak yang tinggi oleh pemerintah bagi sektor } \\
\text { peternakan }\end{array}$ & 0.077 & 2 & 0.154 \\
\hline \multirow[t]{2}{*}{ Total } & 0.083 & 3 & 0.249 \\
\hline & & & 3.085 \\
\hline
\end{tabular}

\section{Analisis Matriks IE Pemasaran Susu Kambing di Bogor}

Matriks IE merupakan gabungan dari matriks IFE dan EFE yang akan menentukan posisi persaingan usaha susu kambing di kota dan kabupaten Bogor. Penggabungan antara matriks IFE sebesar 2.701 dengan matriks EFE sebesar 3.085 menempatkan posisi persaingan usaha susu kambing di kota dan kabupaten Bogor berada pada sel II, yaitu daerah tumbuh dan membangun (grow and build). Strategi yang sesuai dengan sel ini adalah strategi intensif, misalnya penetrasi pasar, pengembangan pasar, dan 
pengembangan produk (David 2009). Penggabungan kedua matriks dan keberadaan posisinya dapat terlihat pada Gambar 1, berikut ini:

Total Skor IFE

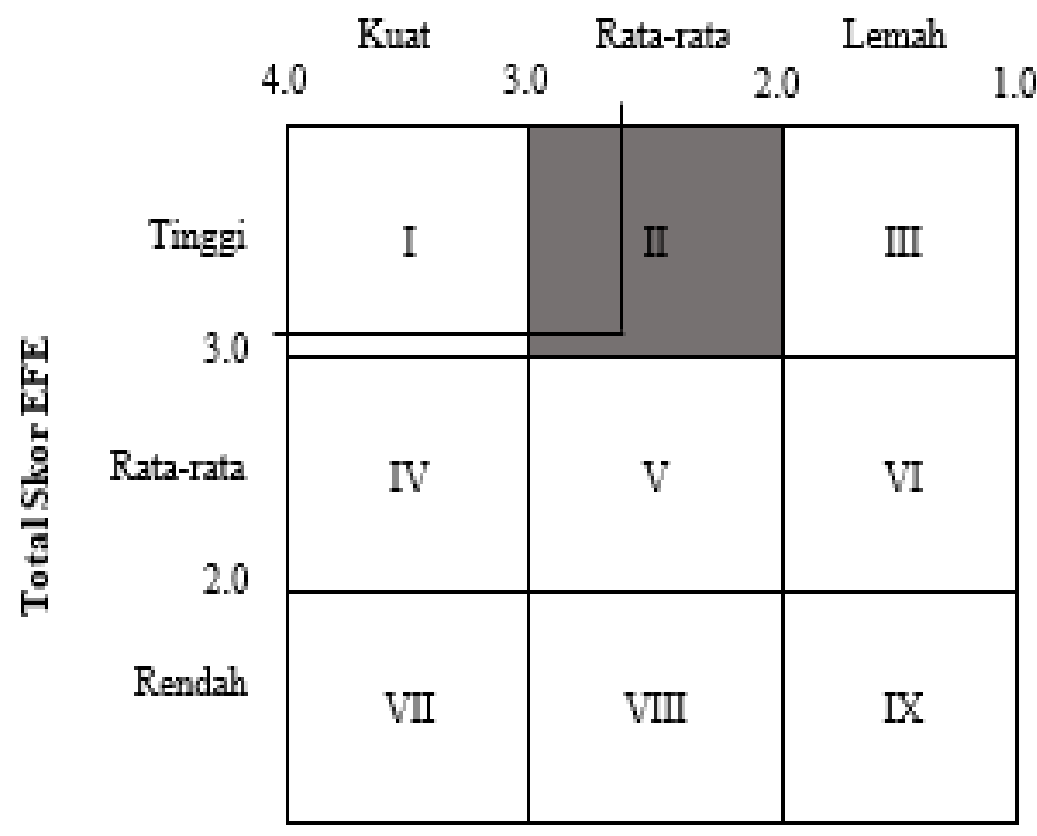

Gambar 1 Matriks SWOT pemasaran susu kambing di Bogor

\section{Analisis Matriks SWOT Pemasaran Susu Kambing di Bogor}

Terdapat tujuh startegi SWOT yang didapat dari penggabungan faktor internal dan eksternal (Tabel 3). Strategi yang dikembangkan untuk usaha susu kambing di Bogor yang sesuai dengan sel II adalah strategi intensif, misalnya penetrasi pasar, pengembangan pasar, dan pengembangan produk. Strategi yang disusun tersebut diharapkan dapat meingkatkan usaha susu kambing di kota dan kabupaten Bogor.

Ketujuh strategi tersebut dibagi ke dalam empat kelompok, yaitu:

1. Strategi S-O

a. Mendorong kesadaran masyarakat untuk hidup sehat dengan memberikan edukasi akan kebaikan mengonsumsi susu kambing

b. Menggencarkan promosi akan kandungan nutrisi susu kambing juga manfaat mengonsumsinya, melalui berbagai bentuk, seperti brosur dan iklan, baik melalui media cetak (koran) maupun media elektronik ( $\mathrm{TV}$, radio, iklan di internet)

2. Strategi S-T

a. Dukungan pemerintah bagi peternak dalam mendapatkan izin edar produk

3. Strategi W-O 
a. Menjadikan pengembangan susu kambing sebagai bagian dari road map pemerintah dalam upaya mengoptimalkan potensi kota dan kabupaten Bogor

4. Strategi W-T

a. Mendirikan GKSI untuk menampung dan menyalurkan susu kambing dari peternak

b. Jaminan keamanan usaha dari pemerintah untuk peternak agar dapat tetap berproduksi tanpa takut merugi

c. Meningkatkan peran asosiasi atau himpunan peternak kambing perah guna meningkatkan bargaining position peternak kambing perah

Tabel 3 Alternatif strategi pemasaran susu kambing di Bogor

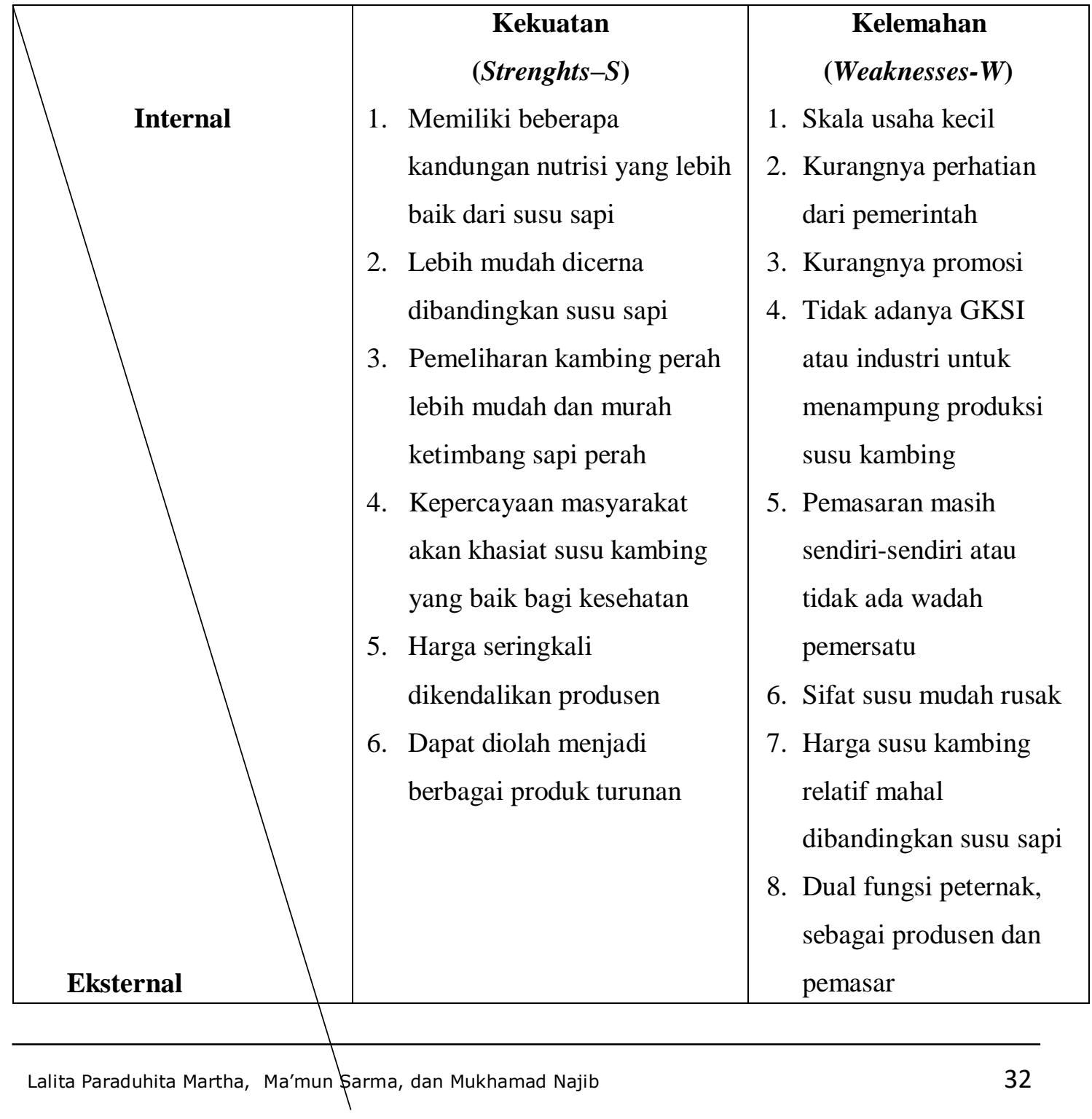




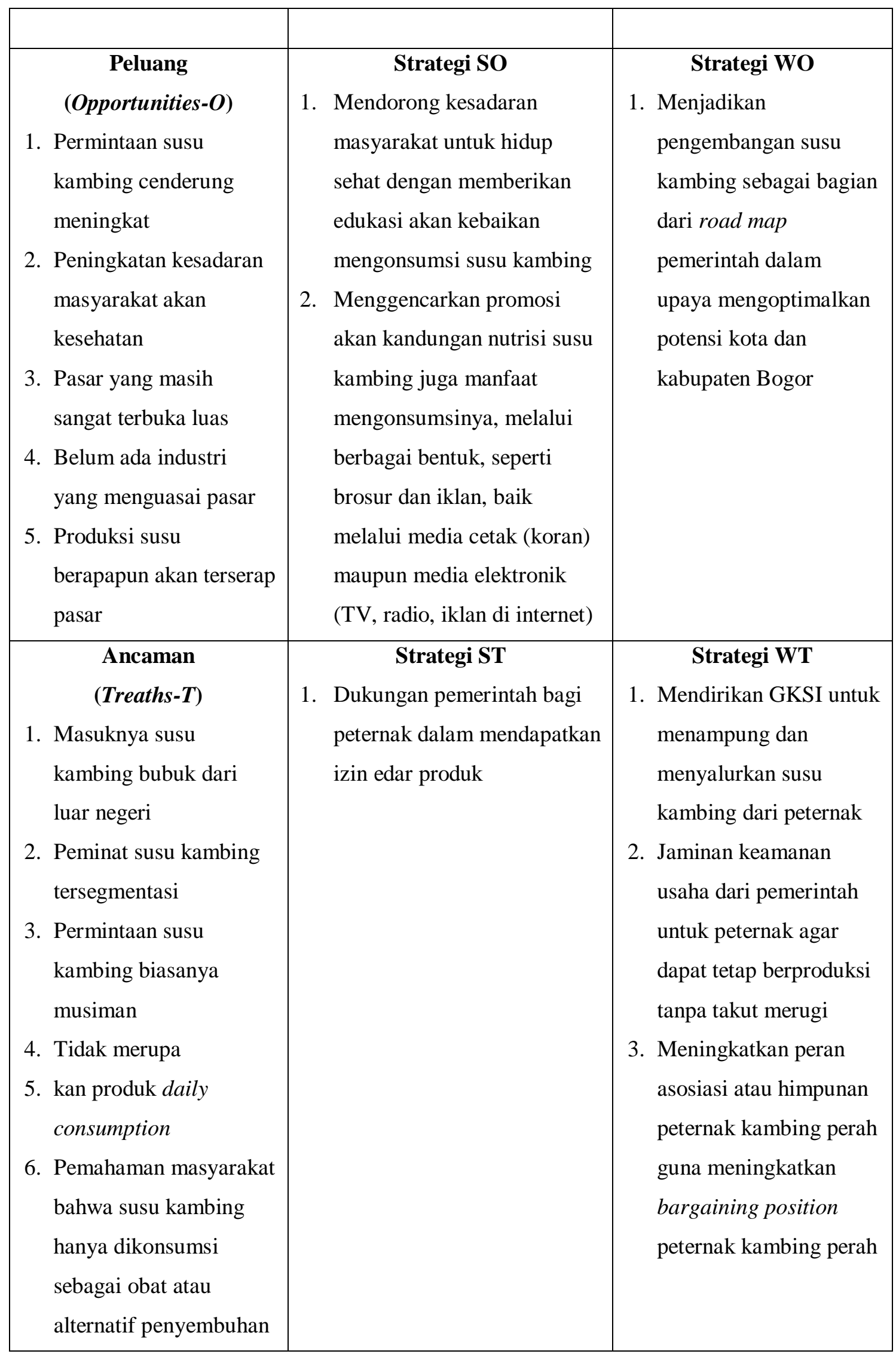


saja

7. Pengenaan pajak yang

tinggi oleh pemerintah

bagi sektor peternakan

Analytical Hierarchy Process

Struktur Hierarki Strategi Peningkatan Pemasaran Susu Kambing di Bogor

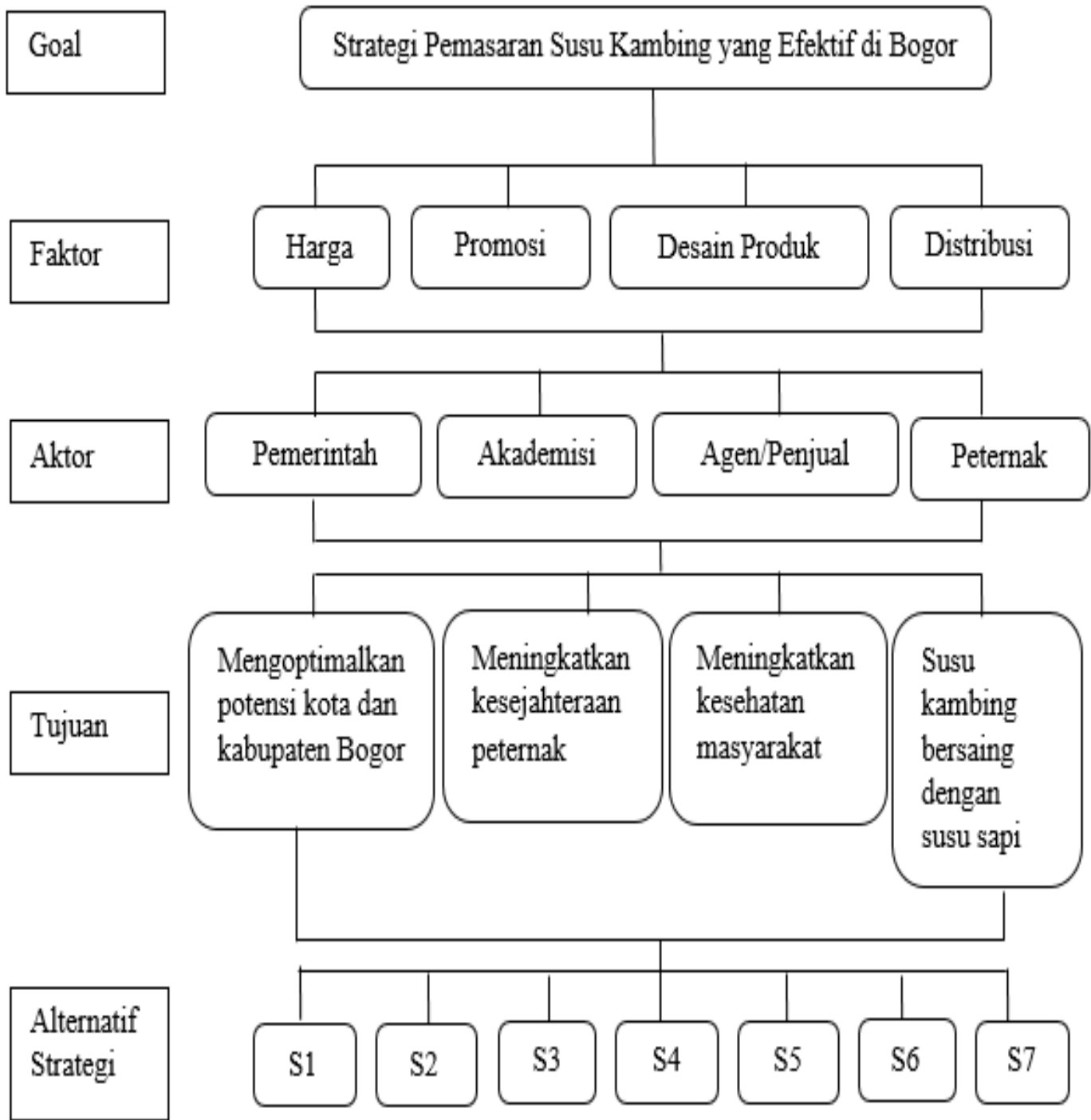

Gambar 2 Hierarki strategi peningkatan pemasaran susu kambing di Bogor

\section{Hasil Pengolahan Proses Hierarki}


Pengolahan hierarki bertujuan untuk mengkaji pengaruh setiap elemen pada hierarki terhadap sasaran utam. Faktor "harga" (0.409), aktor "peternak " (0.464), tujuan "susu kambing bersaing dengan susu sapi“" (0.475), serta alternatif strategi "menjadikan pengembangan susu kambing sebagai bagian dari road map pemerintah dalam upaya mengoptimalkan potensi kota dan kabupaten Bogor" (0.202) merupakan elemen dalam hierarki yang paling berpengaruh terhadap sasaran utama "strategi peningkatan pemasaran susu kambing di Bogor" (Gambar 3).

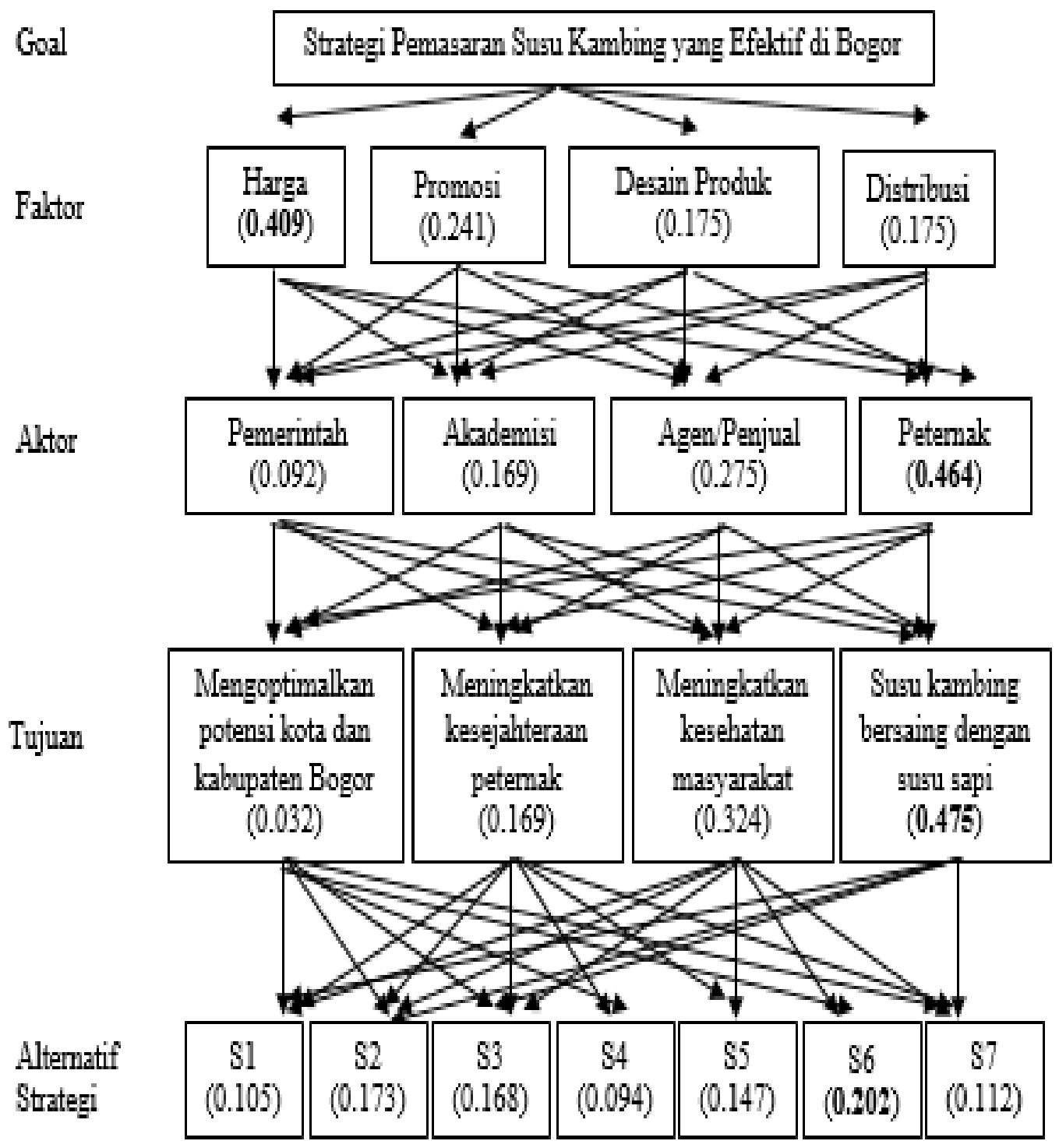

Gambar 3 Hierarki strategi peningkatan pemasaran susu kambing di Bogor

\author{
SIMPULAN DAN SARAN
}




\section{Simpulan}

1. Faktor internal usaha susu kambing di Bogor memiliki total skor internal sebesar 2.701 yang menunjukkan bahwa posisi internal usaha susu kambing saat ini cukup kuat. Kekuatan utama yang mendukung usaha susu kambing adalah "kepercayaan masyarakat akan khasiat susu kambing yang baik bagi kesehatan“, sedangkan kelemahan usaha susu kambing di Bogor adalah "skala usaha kecil". Faktor eksternal usaha susu kambing di Bogor memiliki total skor internal sebesar 3.085 yang menunjukkan bahwa posisi eksternal usaha susu kambing saat ini kuat. Peluang terbesarnya adalah "pasar yang masih sangat terbuka luas", sedangkan ancaman utama pada usaha susu kambing adalah "peminat susu kambing tersegmentasi“.

2. Rekomendasi prioritas strategi utama untuk peningkatan pemasaran susu kambing di Bogor berdasarkan analisis AHP yang diperoleh dari hasil analisis SWOT, berturutturut yaitu menjadikan pengembangan susu kambing sebagai bagian dari road map pemerintah dalam upaya mengoptimalkan potensi kota dan kabupaten Bogor (S6); mendorong kesadaran masyarakat untuk hidup sehat dan menjaga kesehatan dengan mengedukasi masyarakat luas akan kebaikan mengonsumsi susu kambing dan komponen gizi yang terkandung dalam susu kambing dan manfaatnya (S2); menggencarkan promosi akan kandungan nutrisi susu kambing beserta manfaat mengonsumsinya dalam berbagai bentuk, seperti brosur dan iklan, baik melalui media cetak (koran) maupun media elektronik (TV, radio, iklan di internet (S3); jaminan keamanan usaha dari pemerintah untuk peternak agar dapat tetap berproduksi tanpa takut merugi (S5); meningkatkan peran asosiasi atau himpunan peternak kambing perah guna meningkatkan bargaining position peternak kambing perah (S7); dukungan pemerintah bagi peternak dalam mendapatkan izin edar produk (S1); mendirikan GKSI untuk menampung dan menyalurkan susu kambing dari peternak (S4).

\section{Saran}

Kepercayaan masyarakat akan khasiat susu kambing yang baik bagi kesehatan merupakan kekuatan utama susu kambing yang sebaiknya dimanfaatkan oleh para peternak dan agen/penjual. Dengan melakukan promosi, manfaat susu kambing dan kandungan mutrisi di dalamnya dapat terpublish, sehingga masyarakat luas akan mau mencoba untuk mengonsumsi susu kambing. Usaha susu kambing yang masih merupakan skala usaha kecil, membutuhkan perhatian dari pemerintah untuk dapat membantu membesarkan skala usaha susu kambing dengan menjadikan susu kambing sebagai 
komoditi ungguian, sehingga susu kambing akan menjadi prioritas perhatian pemerintah. Untuk mengatasi peminat susu kambing yang tersegmentasi, pemasar harus dapat membuat konsumen yang sudah mengonsumsi susu kambing merasa ada di jalur yang benar dengan pola konsumsi mereka masing-masing, dan sebaliknya membuat calon konsumen yang belum pernah mengonsumsi susu kambing sebelumnya untuk segera menyusul menjadi pengonsumsi susu kambing. Hal tersebut dapat dilakukan oleh pemasar dengan menerapkan market education pada para target pasar. Jika para target pasar tersebut sudah teredukasi dengan baik, maka pasti jumlah konsumen susu kambing akan semakin meningkat dan disertai pula dengan tingkat kemajuan gizi dan perkembangan generasi muda yang semakin berkualitas. Selain itu, usaha susu kambing memiliki pasar yang masih sangat terbuka luas, maka dari itu perlu dukungan semua pihak yang terlibat dalam usaha susu kambing untuk turut serta membantu meningkatan pemasaran susu kambing dan menjadikan keberadaannya bermanfaat untuk banyak orang.

\section{DAFTAR PUSTAKA}

David FR. 2009. Konsep Manajemen Stratgeis. Ed ke-12. Jakarta (ID): Salemba Empat.

Farid M dan Sukesi H. 2011. Pengembangan Susu Segar dalam Negeri untuk Pemenuhan Kebutuhan Susu Nasional. Buletin Ilmiah Litbang Perdagangan [Internet]. [diunduh 2014 Maret 20]; 5(2):196-221. Tersedia pada: http://www.google.co.id/url?sa=t\&rct=j\&q=\&esrc=s\&source=web\&cd $=1 \&$ ved=0CB4QFjAA\&url=http $\% 3 \mathrm{~A} \% 2 \mathrm{~F} \% 2 \mathrm{Fwww}$. kemendag.go.id $\% 2 \mathrm{Ffils}$ \%2Fpdf\%2F2013\%2F04\%2F26\%2F1366948215.pdf\&ei=6X3DU6nyGWfu gTE54K4BQ\&usg=AFQjCNEq0jwm5Pah9skpdduW-V0Ta6yJng.

Istijanto. 2005. Aplikasi Praktis Riset Pemasaran. Jakarta (ID): Gramedia Pustaka Utama. Iwantoro S. 2014. Government Policy on Dairy Goat Development in Indonesia. Di dalam: Wiryawan KG, Liang JB, Devendra C, Takahashi J, Orskov ER, Astuti DA, Manalu W, Jayanegara A, Tjakradidjaja AS, Suharti S, Erief II, Evvyernie D, editor. The Role of Dairy Goat Industry in Food Security, Sustainable Agriculture Production, and Economic Communities. The 2nd Asian-Australian Dairy Goat Conference; 2014 April 25-27; Bogor, Indonesia. Bogor (ID): FAPET IPB. hlm 3-7. 